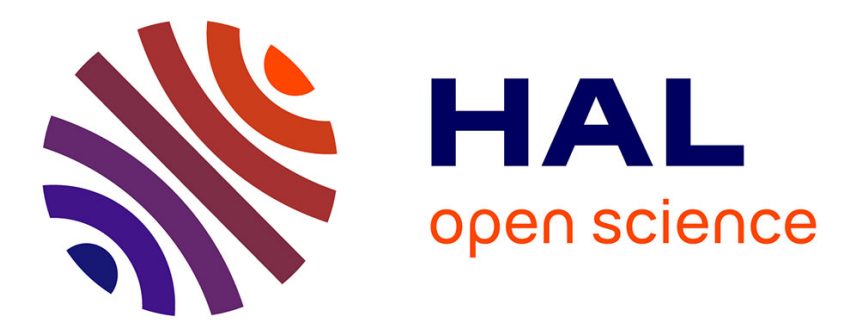

\title{
Precambrian palaeontology in the light of molecular phylogeny - an example: the radiation of the green algae B. Teyssèdre
}

\section{To cite this version:}

B. Teyssèdre. Precambrian palaeontology in the light of molecular phylogeny - an example: the radiation of the green algae. Biogeosciences Discussions, 2007, 4 (5), pp.3123-3142. hal-00330266

\section{HAL Id: hal-00330266 https://hal.science/hal-00330266}

Submitted on 10 Sep 2007

HAL is a multi-disciplinary open access archive for the deposit and dissemination of scientific research documents, whether they are published or not. The documents may come from teaching and research institutions in France or abroad, or from public or private research centers.
L'archive ouverte pluridisciplinaire HAL, est destinée au dépôt et à la diffusion de documents scientifiques de niveau recherche, publiés ou non, émanant des établissements d'enseignement et de recherche français ou étrangers, des laboratoires publics ou privés. 
Biogeosciences Discuss., 4, 3123-3142, 2007

www.biogeosciences-discuss.net/4/3123/2007/

(c) Author(s) 2007. This work is licensed

under a Creative Commons License.

Biogeosciences Discussions is the access reviewed discussion forum of Biogeosciences

\section{Precambrian palaeontology in the light of molecular phylogeny - an example: the radiation of the green algae}

\section{B. Teyssèdre}

University Paris I, 12 place du Panthéon, 75.005 Paris, France

Received: 23 April 2007 - Accepted: 3 May 2007 - Published: 10 September 2007

Correspondence to: B. Teyssèdre (bteyssedre@wanadoo.fr)
BGD

4, 3123-3142, 2007

The Precambrian radiation of the green algae

B. Teyssèdre

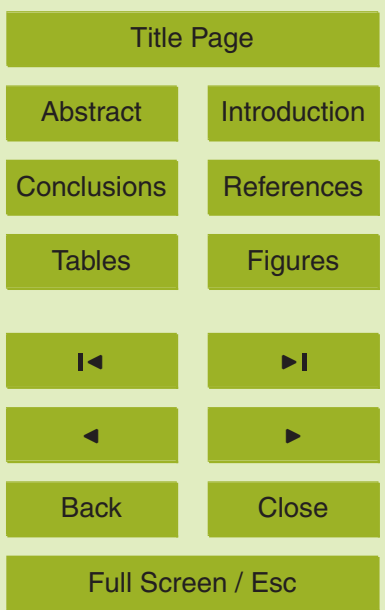

Printer-friendly Version

Interactive Discussion 


\section{Abstract}

The problem of the antiquity of the radiation of the green algae (phylum Viridiplantae) has been hotly debated and is still controversial today. A method combining Precambrian paleontology and molecular phylogeny is applied to shed light on 5 this topic. As a critical method, molecular phylogeny is essential for avoiding taxonomic mistakes. As a heuristic method, it helps us to discern to what extent the presence of such and such clade is likely at such and such time, and it may even suggest the attribution of some fossil to a clade whose taxonomic position will be distinctly defined even though it has no previously known representative.

10 Some well characterized Precambrian fossils of green algae are Palaeastrum and Proterocladus at Svanbergfjellet (ca. $750 \mathrm{Ma}$ ), Tasmanites and Pterospermella at Thule (ca. $1200 \mathrm{Ma}$ ), Spiromorpha at Ruyang (ca. $1200 \mathrm{Ma}$ ) and Leiosphaeridia crassa at Roper (ca. $1450 \mathrm{Ma}$ ). The position of these fossils in the taxonomy and the phylogeny of the Viriplantae is discussed. The conclusions are that the Chlorophyceae and the Ulvophyceae were separated long before $750 \mathrm{Ma}$, that the Chlorophyta and the Streptophyta were separated long before $1200 \mathrm{Ma}$ and that the last common ancestor of the Viridiplantae and the Rhodophyta was possibly two billion years old.

\section{Introduction}

One of the purposes of molecular phylogeny is to estimate the taxonomic gap between two taxons by computing the number of mutations that some of their molecules have undergone since the two lineages diverged. What is the relation, you might ask, between a comparative analysis of sequences of nucleic acids or proteins and Precambrian palaeontology?

On the one hand, although molecular phylogeny does not always allow us to establish an exact taxonomy, it helps us to detect gross errors due to homoplasy or morphological convergence. If a palaeontologist avoids this interdisciplinary collation,
BGD

4, 3123-3142, 2007

The Precambrian radiation of the green algae

B. Teyssèdre

\section{Title Page}

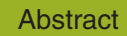

Introduction

Conclusions

Tables

References

Figures

14

$\rightarrow$

$<$

Back

Close

\section{Full Screen / Esc}

Printer-friendly Version

Interactive Discussion 
he lays himself open to a misinterpretation of the true relationships of the fossils. Furthermore molecular phylogeny allows us to determine the order of the nodal points that mark the successive evolutionary stages in a phylum. This order is an important criterion for evaluating the probability that a fossil discovered at a given geological level does or does not belong to a given taxonomic clade.

As an example of the usefulness of a method combining Precambrian palaeontology and molecular phylogeny, we may consider the problem of the antiquity of the radiation of the green algae (phylum Viridiplantae). This topic has been hotly debated and is still controversial today. Cavalier-Smith $(2002,2006)$, using molecular phylogeny but not 10 palaeontology, assumed that the Eukaryotes are not older than 900 million years and the Plantae not older than $650 \mathrm{Ma}$. Knoll (2003), using palaeontology but not molecular phylogeny, asserted that the most ancient fossils of green algae are ca. $750 \mathrm{Ma}$ old and that the Viridiplantae separated from the Rhodophyta not much before $1200 \mathrm{Ma}$. However Teyssèdre $(2002,2006)$ concluded that their point of divergence goes back

15 much earlier, certainly before $1200 \mathrm{Ma}$, most probably before $1450 \mathrm{Ma}$ and possibly ca. $2000 \mathrm{Ma}$. The present paper is an attempt to demonstrate this third theory, using a method that associates both palaeontology and molecular phylogeny.

Let us first place some landmarks in Precambrian palaeontology.

\section{Some landmarks on the most ancient radiations of the Viridiplantae}

20 Butterfield et al. (1994) discovered at Svanbergfjellet, Spitzbergen, ca. $750 \mathrm{Ma}$, many well preserved fossils belonging to two kinds of green algae of essentially modern aspect. Proterocladus designates multicellular uniseriated filaments sometimes laterally ramified. Two species, $P$. major and $P$. minor, look like the living Cladophora in that each filament is made of many individual cells separated by septa, each cell being cylindrical, thin-walled, and the branches generally underlying a septum on the primary axis. A third species, $P$. hermannae, looks rather like the living Cladophoropsis in that a coenocytic multinucleated cytoplasm splits at irregular intervals and emits

BGD

4, 3123-3142, 2007

The Precambrian radiation of the green algae

B. Teyssèdre

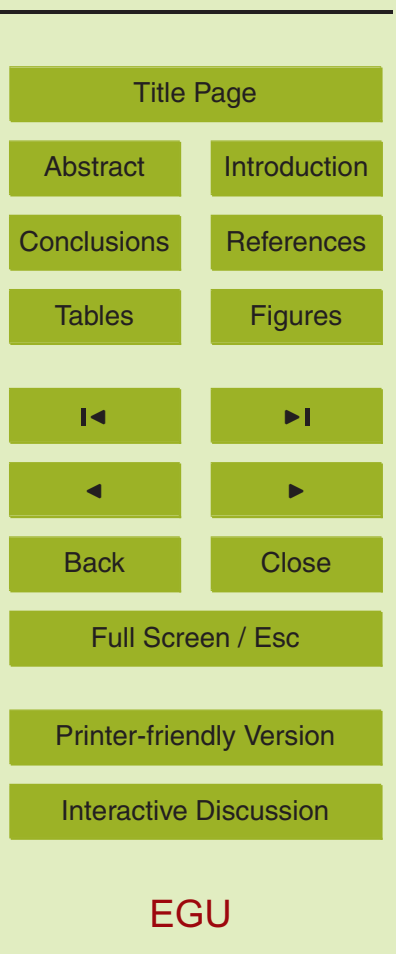


an intermediary septum before initiating a lateral branch. Palaeastrum designates a monostromatic colony of spheroid or ellipsoid coccoid cells linked together by prominent disks, like the living Pediastrum. More accurately it resembles the living Coelastrum in that the border of the intercellular disks is greatly strengthened.

5 Butterfield et al. (1994) recognized in Proterocladus the diagnostic characters of the Ulvophyceae and in Palaeastrum that of the Chlorophyceae. They classified the former as a Siphonocladale and the latter as a Chlorococcale.

A primitive type of unicellular Chlorophyta, characterized by the minute scales coating their cellular body and their flagella, is traditionally named "Prasinophycae". 10 Among them several recent representatives of the order Pyramimonadales possess a distinctive feature that has been highly favourable to the preservation of their fossil parents. Their cycle of life is not limited to a motile stage during which the alga actively swims using its flagella; it also comprises a stage that has no exact equivalent in any other clade, called "phycoma". Although it is not motile, a phycoma differs from a cyst or 15 a spore in that it is not inert or "quiescent". Instead the cell remains metabolically active and its volume considerably increases inside a porous envelope through which it feeds from the external medium by osmosis. This envelope, although flexible, is extremely resistant to hydrolysis and acetolysis.

Samuelsson et al. (1999) demonstrated that four morphotypes of the 20 "Prasinophycae" (or more accurately speaking, of the Pyramimonadales) coexisted at Thule, Greenland, ca. $1200 \mathrm{Ma}$. They considered two of them to be closely related to algae still living today: Tasmanites looks like Pachysphaera by the pores that perforate its shell and Pterospermella shares with Pterosperma an annular membranous "wing". Simia, typified by its double envelope, and an

25 acanthomorph close to Vandalosphaeridium probably represent other lineages of Pyramimonadales extinct without any representatives today. Possibly these taxons had much older forerunners (Mendelson and Schopf, 1992): a spheromorph with coarse pores named Trematosphaeridium holtedahlii looks like a primitive Tasmanites at Zigazino-Komarovsk ca. $1350 \mathrm{Ma}$ and at Balkal ca. $1500 \mathrm{Ma}$. In the same

BGD

4, 3123-3142, 2007

\section{The Precambrian radiation of the green algae}

B. Teyssèdre

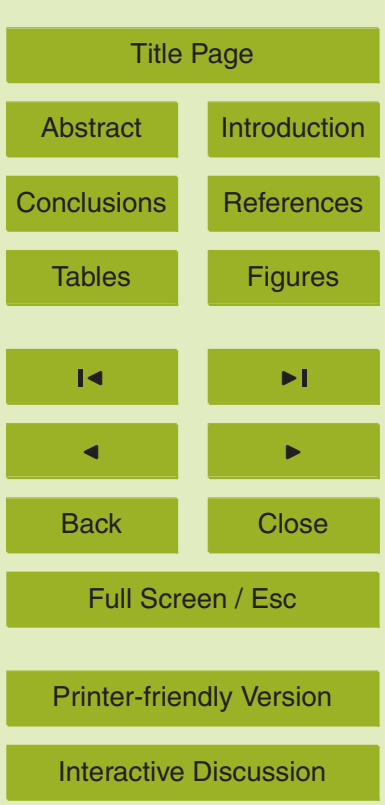

EGU 
way, Pterospermopsimorpha capsulata at Zigazino-Komarovsk ca. $1350 \mathrm{Ma}$ and Eomarginata striata at Bakal and Satka ca. $1500 \mathrm{Ma}$ are apparently precursors of the "equatorial wing" of Pterospermella - but perhaps these pecularities are merely diagenetic alterations due to the poor preservation of these very ancient actitarchs.

5 Concerning the second subphylum of the Viridiplantae, the Streptophyta (the Chlorophyta being the first), Yin et al. (2005) recently found at Ruyang, North China, ca. $1200 \mathrm{Ma}$, an organic-walled microfossil that displays a "navicular" (spindle-like) shape with two rounded ends and no processes. The interior of the vesicle is not divided by septa or diaphragm. The wall surface, smooth or granular, bears 8-12 10 furrows, stripes or grooves, each $1 \mu \mathrm{m}$ wide, coiled spirally from one end to another and separated by uneven intervals $5-18 \mu \mathrm{m}$ wide. The morphological features of this fossil, named Spiromorpha segmentata, are strikingly reminiscent of the zygospores of the still living Zygnematophyceae Spirotaenia, except that the spindle of the latter is more elongated. The Zygnematophyceae set apart from all the other Streptophyta by 15 their peculiar way of reproduction, namely a sexual conjunction between two adjacent cells or filaments that produces a diploid zygospore (hence they are also named "Conjugaphyceae"). The attribution of Spiromorpha to this clade is strengthened by the observation that a specimen of Ruyang shows a conjunction between two cells.

The name "Leiosphaeridia" means nothing but a pseudo-taxon. It was used as a wastebasket for housing a crowd of acritarchs whose shared characters are only a spheroid shape and a smooth envelope without any spine or adornment. So their resemblance with the Pyramimonadale Halosphaera is misleading. However some of them are probably genuine green algae. For instance $L$. ferquensis, from the upper Devonian of France, ca. $380 \mathrm{Ma}$, is clearly akin to Tasmanites by the pores perforating 25 its shell (Abadie and Taugourdeau-Lantz, 1982). L. wenlockia, from the middle Silurian of Gotland, ca. $426 \mathrm{Ma}$, has exactly the same excystment split as the specimens of Pterospermella found at the same site (Le Herissé, 1984). L. crassa from Roper, Australia, ca. $1450 \mathrm{Ma}$, is coated by a "trilaminar structure" (TLS) without equivalent today outside of the Chlorophyta (Javaux et al., 2004). The same TLS is seen, a billion

BGD

4, 3123-3142, 2007

\section{The Precambrian radiation of the green algae}

B. Teyssèdre

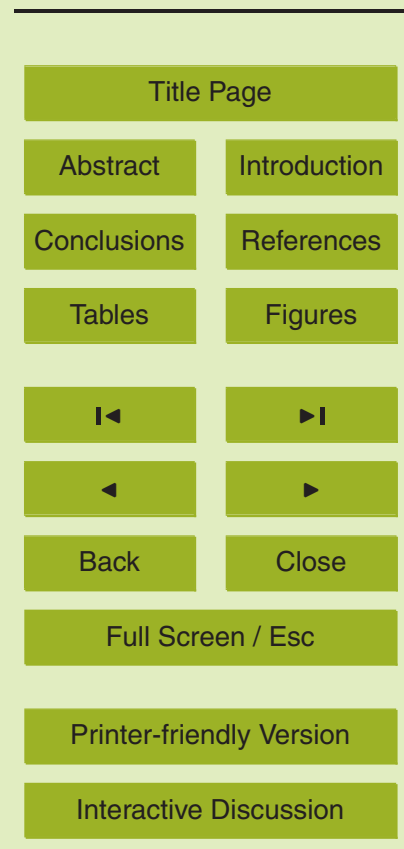

EGU 
years later, on some "Leiosphaeridia sp." from the early Cambrian of Estonia (Talyzina and Moczydowska, 2000).

Some acritarchs found at Chuanlinggou, China, ca. 1730-1700 Ma (Yan, 1982; Huntley et al., 2006), share with the living Pyramimonadales two outstanding 5 characteristics: the same unadorned spheromorphic body ("leiosphaerid") can be of variable size like a living phycoma (Stictosphaeridium for instance), and its envelope can bear a semicircular splitting as for excystment (Schizofusa).

A great deal of microspheromorphs have been preserved in Russian deposits 1800-2000 Ma old. Timofeev (1982) has obtained most of them using a method 10 that Eisenack had perfected for extracting the pollen seeds of fossil plants from their gangue: he soaked the matrix containing the pollen in hydrofluoric acid to which it is resistant. The envelope of acritarchs that withstand such a drastic treatment must possess some biopolymer like the sporopollinins or the algaenans, that are today almost exclusively typical of the Viridiplantae. So the last common ancestor of the 15 Viriplantae and the Rhodophyta was perhaps two billion years old.

\section{Molecular phylogeny as a critical method for controlling the taxonomy of the fossils}

Let us go to the next step. Let us bring face to face the discoveries of palaeontology and the analyses of molecular phylogeny. We shall review our Precambrian landmarks using molecular phylogeny from two successive points of view, first as a critical method for controlling the taxonomy of the fossils and second as a heuristic tool for deciphering their meaning in the evolution of the Viridiplantae.

The best characterized Precambrian fossils of green algae are Palaeastrum and Proterocladus at Svanbergfjellet (ca. $750 \mathrm{Ma}$ ), Tasmanites and Pterospermella at Thule (ca. $1200 \mathrm{Ma}$ ) and Spiromorpha at Ruyang (ca. $1200 \mathrm{Ma}$ ).

Butterfield et al. (1994) classified Palaeastrum as a Chlorococcale akin to the living Pediastrum and Coelastrum. However the comparative analyses of SSU

BGD

4, 3123-3142, 2007

The Precambrian radiation of the green algae

B. Teyssèdre

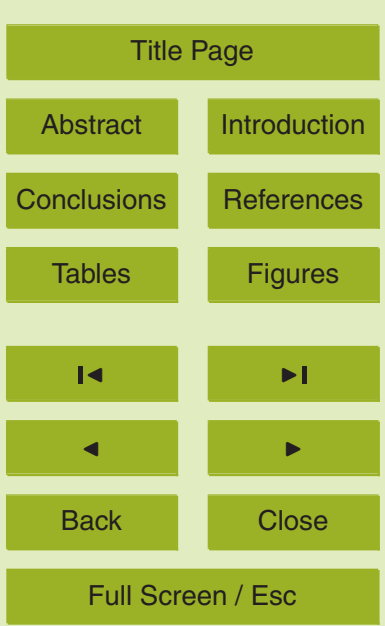

Printer-friendly Version

Interactive Discussion 
rRNA sequences demonstrated that the word "Chlorococcale" does not indicate any genuine clade. It denotes a highly polyphyletic cluster of many independant lineages (about thirty) proceeding from three distinct classes of the Chlorophyta, the Chlorophyceae, Ulvophyceae and Trebouxiophyceae. For instance five species of the 5 "Chlorococcalean" pseudo-genus Neochloris belong to four clades each of which is very remote from the others and scattered among these three classes (Watanabe and al., 2000). Moreover species of the recent genus Pediastrum (polyphyletic itself) are related to Hydrodictyon while Coelastrum is related to Scenedesmus, and both are distantly connected to Sphaeroplea. So Palaeastrum is not a "Chlorococcale", 10 as the palaeontologists who found it said. It may more accurately be classified as a Chlorophyceae member of a subset of the order Sphaeropleales that includes the "families" Hydrodictyaceae and Scenedesmaceae (Buchheim and al., 2001).

According to Butterfield et al. (1994) Proterocladus, again at Svanbergfjellet, comprises three species, two of which ( $P$. major and $P$. minor) are supposed to be akin to the living Cladophora and the third ( $P$. hermannae) akin to Cladophoropsis. These two recent genera are supposed to differ in that the filaments of the first type are made of many individual cells separated by septa while in the second type a coenocytic multinucleate cytoplasm splits at various intervals, producing lateral branches and intermediate septa. However molecular analysis showed that the "genus" Cladophora is deeply polyphyletic (Hanyuda et al., 2002). It artificially groups many distinct lineages with which two separated lineages of Cladophoropsis are intermingled. It is obvious that a Cladophoropsis-like coenocytic thread evolved several times independently from a Cladophora-like multicellular filament. So Proterocladus hermannae became coenocytic from a multicellular ancestor like $P$. major and $P$. minor without any relation with the living Cladophoropsis. Proterocladus is not an ancient parent of the recent pseudo-genus Cladophora or Cladophoropsis, both devoid of any real unity, but it belongs to the branch of the Ulvophyceae leading to the recent Cladophorales considered as a whole.

The SSU rRNA of the living Pyramimonadales (Nakayama et al., 1998; Fawley et

\section{BGD}

4, 3123-3142, 2007

\section{The Precambrian radiation of the green algae}

B. Teyssèdre

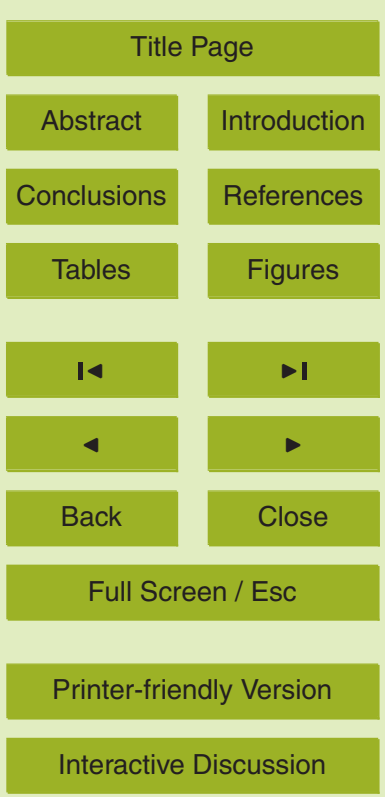

EGU 
al., 2000; Guillou et al., 2004) shows that this clade subdivides in two parts. The first one unites Pyramimonas with Pterosperma (probably with Pachysphaera too, but no molecular analysis of this genus is available today). The second unites Halosphaera with Cymbomonas. Pterosperma, Pachysphaera and Halosphaera produce phycomas.

5 Pyramimonas and Cymbomonas produce quiescent cysts but no phycomas sensu stricto. Tasmanites is a fossil parent of the living Pachysphaera if we judge by the pores that pierce its wall and Pterospermella is an ancestor of the living Pterosperma if we judge by the membranous equatorial "wing" of its shell. Many acritarchs named "Leiosphaeridia" look like the phycoma of Halosphaera but this may be merely 10 convergent and due to the lack of positive discriminating character. Remember that some acritarchs extracted from Thule ca. 1200 Ma were identified by Samuelsson and al. (1999) as Tasmanites, some as Pterospermella, and that each of these two taxons may have had forerunners going back to 1350 or even $1500 \mathrm{Ma}$. Moreover the plentiful spheromorphs of Thule described as "Leiosphaeridia" included almost certainly some phycomas (albeit not necessarily related to Halosphaera). We must conclude that the branch of the Pyramimonadales that leads to the recent Pachysphaera, Pterosperma and Pyramimonas was already separated $1200 \mathrm{Ma}$ ago, and possibly 1350 or even $1500 \mathrm{Ma}$ ago, from the branch leading to the recent Halosphaera and Cymbomonas.

On morphological grounds the class Zygnematophyceae has been divided into three "families", Zygnemataceae, Desmidiaceae (or placoderm desmids) and Mesotaeniaceae (or saccoderm desmids). Spiromorpha, according to Yin et al. (2005), belongs to the third one. However molecular phylogeny shows that such taxonomy is highly arbitrary. The so-called "Mesotaeniaceae" are nothing but a cluster of half a dozen unrelated genera, each of them being related to a genus positioned somewhere else: Mesotaenium near Mougeotia, Cylindrocystis near Zygnemopsis, Spirotaenia near Sirogonium and Spirogyra, Netrium near the stem of the Desmidiaceae, and so on (Besendahl and Bhattacharya, 1999; Deboh et al., 2001; McCourt and al., 2000). Spiromorpha therefore does not belong to the "Mesotaeniaceae" which is merely a pseudo-taxon. Instead this fossil stays, with the living Spirotaenia, Sirogonium and

BGD

4, 3123-3142, 2007

\section{The Precambrian radiation of the green algae \\ B. Teyssèdre}

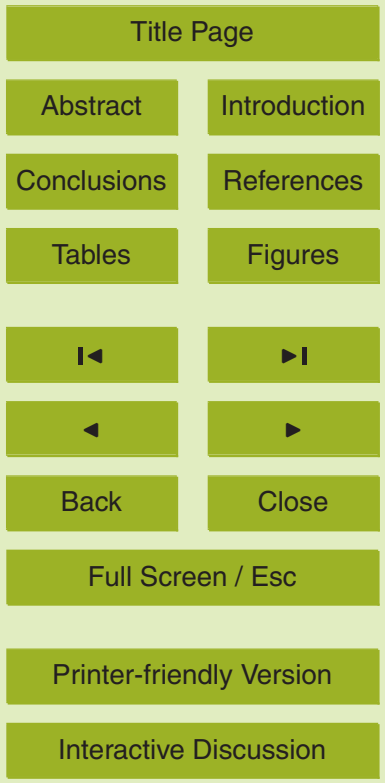

EGU 
Spirogyra, on a line that diverged from the main branch of the Zygnemataceae just after the separation of the holophyletic Desmidiaceae - not properly at the root of the Zygnematophyceaen tree, yet not very far from its stem. So molecular phylogeny allows us to assign to Spiromorpha a well-defined position on the dendrogram, while setting it among "Mesotaeniaceae" was meaningless.

\section{Molecular phylogeny as a heuristic tool for retracing the evolution of the Viridiplantae}

The principle of using molecular phylogeny as a heuristic method for retracing the hidden evolution of a given clade is quite simple. We must first determine a sequence of nodal points in the main branches of the phylogenetical tree. If species $A$ and $B$ coexisted at a given geological time and if a species $C$ diverged from this branch of the tree before the nodal point which marks the last common ancestor of species $A$ and $B$, then the line leading to species $C$ was necessarily differentiated before the geological period when species $A$ and $B$ are attested, even if this line has left no evidence at all among the fossils. Correspondingly a bough that would sprout up near the top of the phylogenetic tree is very unlikely to be represented at geological levels where palaeontologists found only fossils very close to the stem of the same tree. For instance the position of the crocodiles among the Sauropsidae and that of the Sauropsidae among the Amniota makes it highly unlikely, or rather impossible a priori, that a fossil of a crocodile could be found at these levels of upper Devonian that contain the most primitive Tetrapoda.

A taxonomy merely based on morphological features commonly divides the Chlorophyta into four classes, the most primitive of them being the Prasinophyceae. However molecular phylogeny demonstrated that such a concept is absolutely unrealistic. The so-called "Prasinophyceae" do not make up a genuine clade. Rather it means the grouping of several paraphyletic lines (six at least) that separated, each one in turn, from the common stem of the Chlorophyta before the last common ancestor

BGD

4, 3123-3142, 2007

The Precambrian radiation of the green algae

B. Teyssèdre

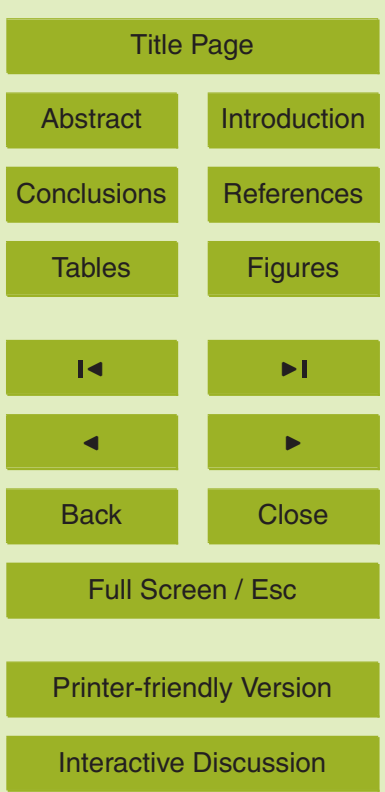

EGU 
of the Chlorophyceae, Ulvophyceae and Trebouxiophyceae. These three last clades, being more advanced than all the preceding ones, would merit to be together termed "Neochlorophyta".

Most palaeontologists relied on merely morphological classifications that do not 5 really mirror the major steps of the diversification of a given clade. If we take into account the comparative analyses of molecular sequences, the significance of the fossils and their mutual relations will be seen in a new light.

Coming back to the fossils found at Svanbergfjellet, we must remember that the Sphaeropleales are part of the Chlorophyceae, the Cladophorales (or

10 Siphonocladales) are part of the Ulvophyceae, and these two classes are part of the most recent radiation of the Chlorophyta. A phylogenetic dendrogram shows that, starting from Palaeastrum or from Proterocladus, we must cross at least twelve nodal points in order to reach the last common ancestor of the Viridiplantae. So the fact that these two taxons were dated ca. $750 \mathrm{Ma}$ does not mean that the most ancient fossils of green algae are $750 \mathrm{Ma}$ old, as Knoll stated (2003). Instead their presence shows that the radiation of the multicellular green algae started long before $750 \mathrm{Ma}$, and that the radiation of the unicellular green algae is even much older.

The find of Spiromorpha at Ruyang conclusively proves that the Streptophyta had no less progressed than the Chlorophyta ca. $1200 \mathrm{Ma}$. Actually Spiromorpha is not very far from the point of origin of the Zygnematophyceae, so this line did not necessarily start much earlier; but the Zygnematophyceae are themselves by no means a primitive clade. They cannot have appeared except after the Klebsormidales, Chlorokybales and Mesostigmatales.

Among six or seven lines of the so-called "Prasinophyceae" still existing today (many others may have disappeared without leaving any trace), the Pyramimonadales are not the most primitive. Yet they are not far from the stem of the Chlorophyta. Indeed they diverged secondly after the Prasinococcales. So if four distinct morphotypes of Pyramimonadales really coexisted at Thule ca. $1200 \mathrm{Ma}$, this implies that this clade was differentiated long ago. Therefore it is not amazing if it is represented among the

BGD

4, 3123-3142, 2007

The Precambrian radiation of the green algae

B. Teyssèdre

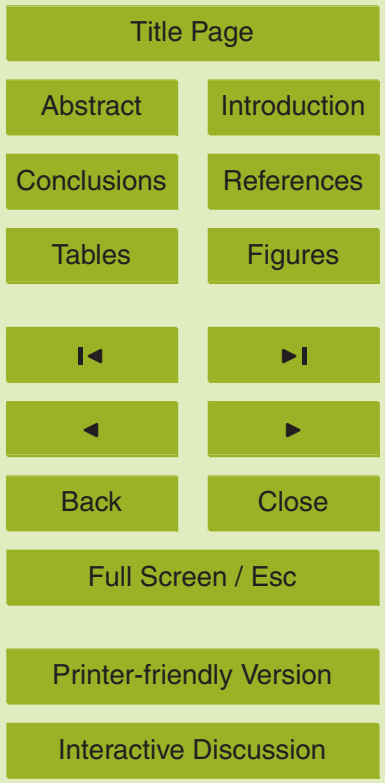

EGU 
most ancient fossils of Eukaryota, ca. $1450 \mathrm{Ma}$ at Roper or even ca. 1730-1700 Ma at Chuanlinggou.

All the fossils presumed to be green algae that have been found at levels 1800-2000 Ma old share the same morphotype: all these are coccoid 5 microspheromorphs without any spine nor adornment. There is no morphological feature that would allow us to distinguish between an acritarch more than one and half billion years old, Protosphaeridium for instance, and a coccoid unicellular Chlorophyte still living today, like Chlorella fusca. Nevertheless the phylogenetical tree of the Viridiplantae allows us to set strict limits to any plausible hypothesis 10 about the taxonomic position of a microfossil that would be very ancient, even if it is devoid of all morphological characterization. Admitting that the Russian acritarchs 1800-2000 Ma old really include some green algae (as the resistance of their shell to acetolysis makes it likely), they must be either some Chlorophyta even older than the Pyramimonadales, like the Prasinococcales, or some extremely archaic Streptophyta,

15 like the Mesostigmatales and Chlorokybales, or lastly, if these most ancient acritarchs are none of these, they may represent a common ancestor of the Chlorophyta and the Streptophyta - i.e. a part of the stem-group of the Viridiplantae whose existence must necessarily be postulated even if it has not left any representative nowadays.

\section{Conclusions}

20 Let us come back to the three aforementioned hypotheses about the antiquity of the green algae.

Cavalier-Smith $(2002,2006)$, being an outstanding specialist of molecular phylogeny but not a palaeontologist, argued that "immensely later" than the outset of the oxygenic age of the Cyanobacteria, and "probably as recently as ca 0.9 Gyr ago, the neomuran 25 revolution ushered in the age of eukaryotes". So the Viridiplantae must be still younger. Palaeontology alone is sufficient to demonstrate that this "neomuran" theory is wrong. If it was right, we might contend that any fossil older than $900 \mathrm{Ma}$ is prokaryotic, even if

BGD

4, 3123-3142, 2007

The Precambrian radiation of the green algae

B. Teyssèdre

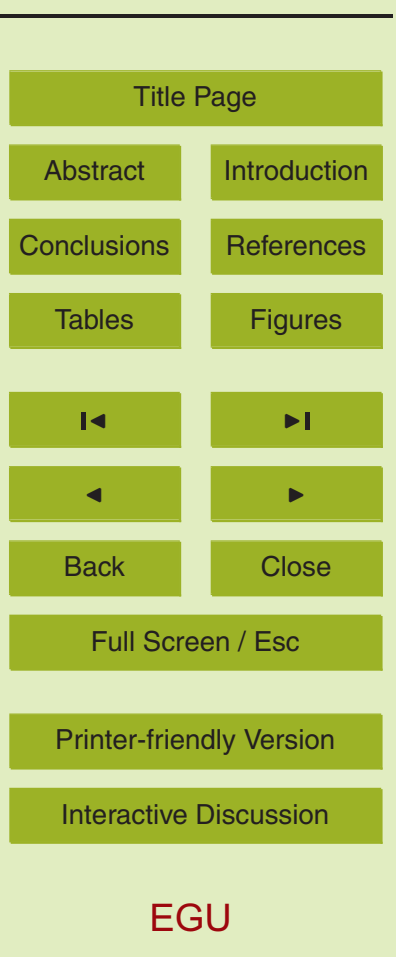


it has such a complex morphology as Bangiomorpha (ca. $1200 \mathrm{Ma}$ ), which indisputably shows the features of a multicellular sexually reproducing Rhodophyta (Butterfield, 2000).

When Knoll (2003) states that the most ancient fossils of green algae are not 5 older than $750 \mathrm{Ma}$, he refers to the fossils of Proterocladus and Palaeastrum found at Svanbergfjellet and he does not consider the Pyramimonadales found at Thule or the Zygnematales found at Ruyang. However these fossils, albeit unicellular, are beyond any doubt genuine green algae. As for the divergence between the Viridiplantae and the Rhodophyta, allegedly not much older than $1200 \mathrm{Ma}$, this idea 10 is a corollary of the theory set out by Knoll (1992) that the radiation of the "crown group of the Eukaryotes" was an explosive "big bang" induced by the fast rise of atmospheric oxygen between 1200 and $1000 \mathrm{Ma}$. If this theory were right, we might assume than every fossil older than $1200 \mathrm{Ma}$ does not belong to the "crown group" of the still living Eukaryotes but is a relic of some evolutive lineage that no longer

exist today. Palaeontology alone, without molecular phylogeny, strongly suggests that this theory is wrong but does not categorically deny it. If one merely points out that a Chlorophyceae (Palaeastrum) coexisted with an Ulvophyceae (Proterocladus) ca. $750 \mathrm{Ma}$ and that a Zygnematophyceae (Spiromorpha) was contemporary with some "Prasinophyceae" (Tasmanites, Pterospermella) ca. $1200 \mathrm{Ma}$, and if one implies that these four classes evolved at the same tempo from the same nodal point of the Viridiplantae, then the point of origin of their last common ancestor is not necessarily very remote. But if we try to determine the position that each of these fossils holds on the dendrogram of the Viridiplantae, we see that the Ulvophyceae and Chlorophyceae are both recent branches on this tree, that they were preceded by a long series of 25 paraphyletic lines of "Prasinophyceae" and that the whole Chlorophyta must have diverged from the Streptophyta much earlier. Then we realize that the phylogenetic tree of the Viridiplantae takes root in a very ancient period, perhaps not far from $2000 \mathrm{Ma}$ (Teyssèdre, 2002, 2006).

The concept that the green and the red algae evolved separately for two billion years
BGD

4, 3123-3142, 2007

\section{The Precambrian radiation of the green algae}

B. Teyssèdre

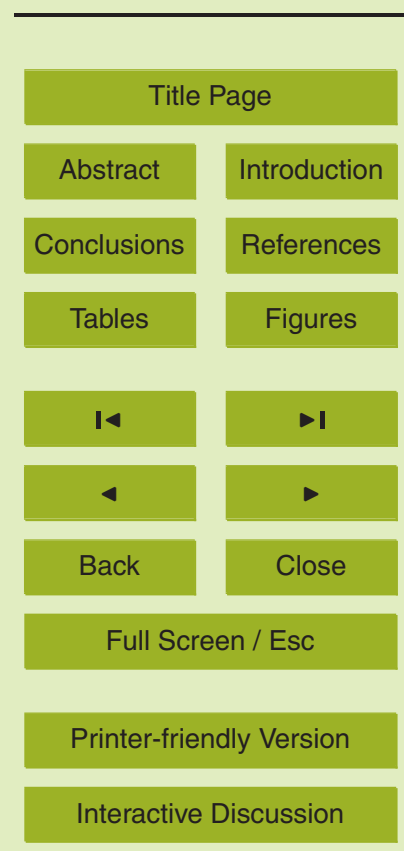

EGU 
looked very unlikely during the 1990s. On the contrary it has become probable since two recent discoveries: a) the presence of steroids in Australian hydrocarbons dated $2700 \mathrm{Ma}$ amounts to a "biochemical signature" suggesting that Eukaryotes already existed at this remote period (Brocks et al., 1999); b) the date of the oxygenation of the 5 atmosphere and oceans that stimulated the Eukaryotic radiation is twice as old as was believed - no longer $1200 \mathrm{Ma}$ (Knoll, 1992) but 2400 Ma (Bekker et al., 2004; Holland, 2006).

In short, molecular phylogeny nowadays has become a necessary complement of palaeontology. As a critical method, it is essential for avoiding taxonomic mistakes. As 10 a heuristic method, it helps us to discern to what extent the presence of such and such clade is likely at such and such time, and it may even suggest the attribution of some fossil to a clade whose taxonomic position will be distinctly defined even though it has no previously known representative.

Acknowledgements. I am grateful to F. Debrenne, J. Le Herissé and P. Janvier for having 15 encouraged my studies in the field of palaeontology; to B. Granier for having recently published my electronic book on the antiquity of green algae and for having kindley authorized me to reproduce two of my phylogenetic trees; to F. Marin and B. Lefebvre for having invited me to present a communication on this topic at the International Symposium "Primitive life, ancient radiations" of Dijon.

\section{References}

Abadie, M. and Taugourdeau-Lantz, J.: Ultrastructure de la paroi de Leiosphaeridia ferquensis (Taug.-Lantz 1969) Taug.-Lantz 1968, Tasmanite du Dévonien supérieur, Bulletin de la Société botanique de France, 129(4-5), 271-275, 1982.

Bekker, A., Holland, H. D., Wang, P. L., Rumble III, D., Stein, H. J., Hannah, J. L., Coetzee, L. L., and Beukes, N. J.: Dating the rise of atmospheric oxygen, Nature, 427, 117-120, 2004.

Besendahl, A. and Bhattacharya, D.: Evolutionary analyses of small-subunit rDNA coding regions and the 1506 group I introns of Zygnematales (Charophyceae, Streptophyta), J. Phycol., 35(3), 560-569, 1999.

BGD

4, 3123-3142, 2007

The Precambrian radiation of the green algae

B. Teyssèdre

Title Page

Abstract

Introduction

Conclusions

Tables

References

Figures

14

$<$

Back

Close

\section{Full Screen / Esc}

Printer-friendly Version

Interactive Discussion 
Brocks, J. J., Logan, G. A., Buick, R., and Summons, R. E.: Molecular fossils and the early rise of Eukaryotes, Science, 285, 1033-1036, 1999.

Buchheim, M. A., Michapulos, E. A., and Buchheim, J. A.: Phylogeny of the Chlorophyceae with special reference to the Sphaeropleales: a study of $18 \mathrm{~S}$ and $26 \mathrm{~S}$ rDNA data, J. Phycol., 37(5), 819-835, 2001.

Butterfield, N. J.: Bangiomorpha pubescens n. gen. n. sp.: implications for the evolution of sex, multicellularity and The Mesoproterozoic-Neoproterozoic radiation of eukaryotes, Paleobiology, 26, 386-404, 2000.

Butterfield, N. J., Knoll, A. H., and Sweet, K.: Paleobiology of the Neoproterozoic Svanbergfjellet Formation, Spitsbergen. Fossils and Strata, 34, 1-84, 1994.

Cavalier-Smith, T.: The neomuran origin of archaebacteria, the negibacterial root of the universal tree and bacterial megaclassification, Int. J. Syst. Evol. Microbiol., 52, 7-76, 2002.

Cavalier-Smith, T.: Cell evolution and Earth history: stasis and revolution. Phil. Trans. R. Soc. B, 361, 960-1006, 2006.

Denboh, T., Hendrayanti, D., and Ichimura, T.: Monophyly of the genus Closterium and the order Desmidiales (Charophyceae, Chlorophyta) inferred from nuclear small subunit rDNA data, Journ. Phycol., 37(5), 1063-1072, 2001.

Fawley, M. W., Yun, Y., and Qin, M. : Phylogenetic analyses of 18S rDNA sequences reveal a new coccoid lineage of the Prasinophyceae (Chlorophyta), Journ. Phycol., 36, 387-393, 202000.

Guillou, L., Eikrem, W., Chrétiennot-Dinet, M. J., Le Gall, F., Massana, R., Romari, K., Pedros-Alio, C., and Vaulot, D. : Diversity of picoplanktonic Prasinophytes assessed by direct nuclear SSU rDNA sequencing of environmental samples and novel isolates retrieved from oceanic and coastal marine ecosystems, Protist, 155, 193-214, 2004.

Hanyuda, T., Wakana, I., Arai, S., Miyaji, K., Watano, Y., and Ueda, K.: Phylogenetic relationships within Cladophorales (Ulvophyceae, Chlorophyta) inferred from 18S rRNA gene sequences, with special reference to Aegagropila linnaei, J. Phycol., 38, 564-571, 2002.

Holland, H. D.: The oxygenation of the atmosphere and oceans, Phil. Trans. R. Soc. B, 361, 903-915, 2006.

so Huntley, J. W., Xiao, S., and Kowalewski, M.: 1.3 Billion years of acritarch history: An empirical morphospace approach, Precambrian Research, 144, 52-68, 2006

Javaux, E. J., Knoll, A. H., and Walter, M. R.: TEM evidence for eukaryotic diversity in mid-Proterozoic oceans, Geobiology, 2, 121-132, 2004.

BGD

4, 3123-3142, 2007

\section{The Precambrian \\ radiation of the green algae}

B. Teyssèdre

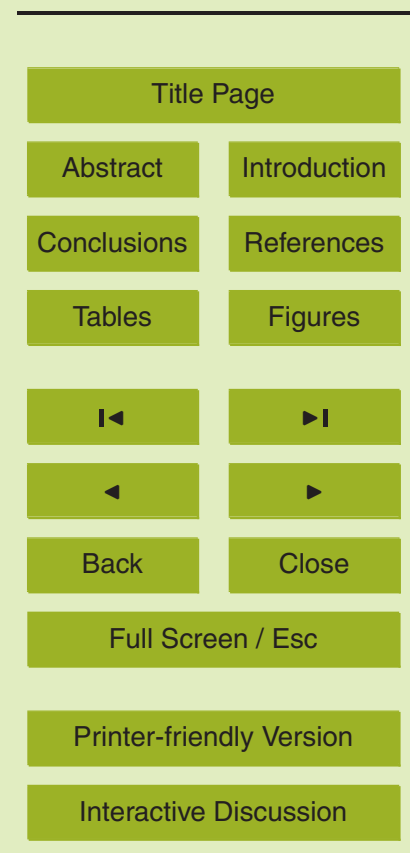

EGU 
Knoll, A. H.: The early evolution of eukaryotes - a geological perspective, Science, 256, 622-627, 1992.

Knoll, A. H.: Life on a young planet. The first three billion years of evolution on earth, Princeton and Oxford, Princeton Univ. Press, 2003.

5 Le Herissé, A.: Microplancton à paroi organique du Silurien de Gotland (Suède): observations au microscope électronique de structures de désenkystement, Rev. Palaeobotany Palynol., 43, 217-236, 1984.

McCourt, R. M., Karol, K. G., Helm-Byclowski, K. M., Grajewska, A., Wojciechowski, M. F., and Hoshaw, R. W.: Phylogeny of the conjugating green algae (Zygnemophyceae) based on rbcL sequences, J. Phycol., 36(4), 744-758, 2000.

Mendelson, C. V. and Schopf, J. W.: Proterozoic and selected Early Cambrian microfossils and microfossil-like objets, in: The Proterozoic biosphere, A multidisciplinary study, edited by: Schopf, J. W. and Klein, C., Cambridge Univ. Press, 867-951, 1992.

Nakayama, T., Marin, B., Kranz, H. D., Surek, B., Huss, V. A. R., Inouye, I., and Melkonian, M.:

15 The basal position of scaly green flagellates among green algae (Chlorophyta) is revealed by analyses of nuclear-encoded SSU rRNA sequences, Protist, 149, 367-380, 1998.

Samuelsson, J., Dawes, P. R., and Vidal, G.: Organic-walled Microfossils from Proterozoic Thule Supergroup, Northwest Greenland, Precambrian Res., 96, 1-23, 1999.

Talyzina, N. M. and Moczydowska, M.: Morphological and ultrastructural studies of some acritarchs studied by using microscopy, fluorescence flow cytometry and biomarkers, Rev. Palaeobotany Palynol., 112, 1-21, 2000.

Teyssèdre, B.: La vie invisible. Les trois premiers milliards d'années de l'histoire de la vie sur terre. Paris, L'Harmattan, 2002.

Teyssèdre, B.: Les algues vertes (phylum Viridiplantae) sont-elles vieilles de deux milliards d'années ? Carnets de Géologie, http://paleopolis.rediris.es/ca/CG2006BOOK01/index. html, 2006.

Timofeev, B. V.: Microfossils of the Early Precambrian. Nauka, Leningrad, 1982.

Watanabe, S., Himizu, A., Lewis, L. A., Floyd, G. L., and Fuerst, P. A.: Pseudoneochloris marina (Chlorophyta), a new coccoid ulvophycean alga, and its phylogenetic position inferred from morphological and molecular data, J. Phycol., 36(3), 596-604, 2000.

Yan, Y.: Schizofusa from the Chuanlinggou Formation of Changcheng System in Jixian County. Bull. Tianjin Inst. Geol. Mineral. Resour. Chin. Acad. Geol. Sci. 6, 1-7, 1982.

Yin, L. M., Yuan, X., Meng, F., and Hu, J.: Protists of the Upper Mesoproterozoic Ruyang Group

BGD

4, 3123-3142, 2007

The Precambrian radiation of the green algae

B. Teyssèdre

Title Page

Abstract

Introduction

Conclusions

References

Tables

Figures

14

-1

4

Back

Close

Full Screen / Esc

Printer-friendly Version

Interactive Discussion 
in Shanxi Province, China. Precambrian Research, 141, 49-66, 2005.

BGD

4, 3123-3142, 2007

The Precambrian radiation of the green algae

B. Teyssèdre

Title Page

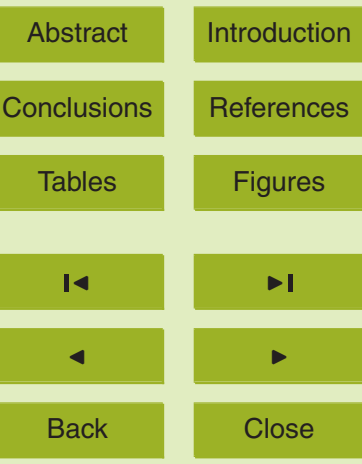

Full Screen / Esc

Printer-friendly Version

Interactive Discussion 


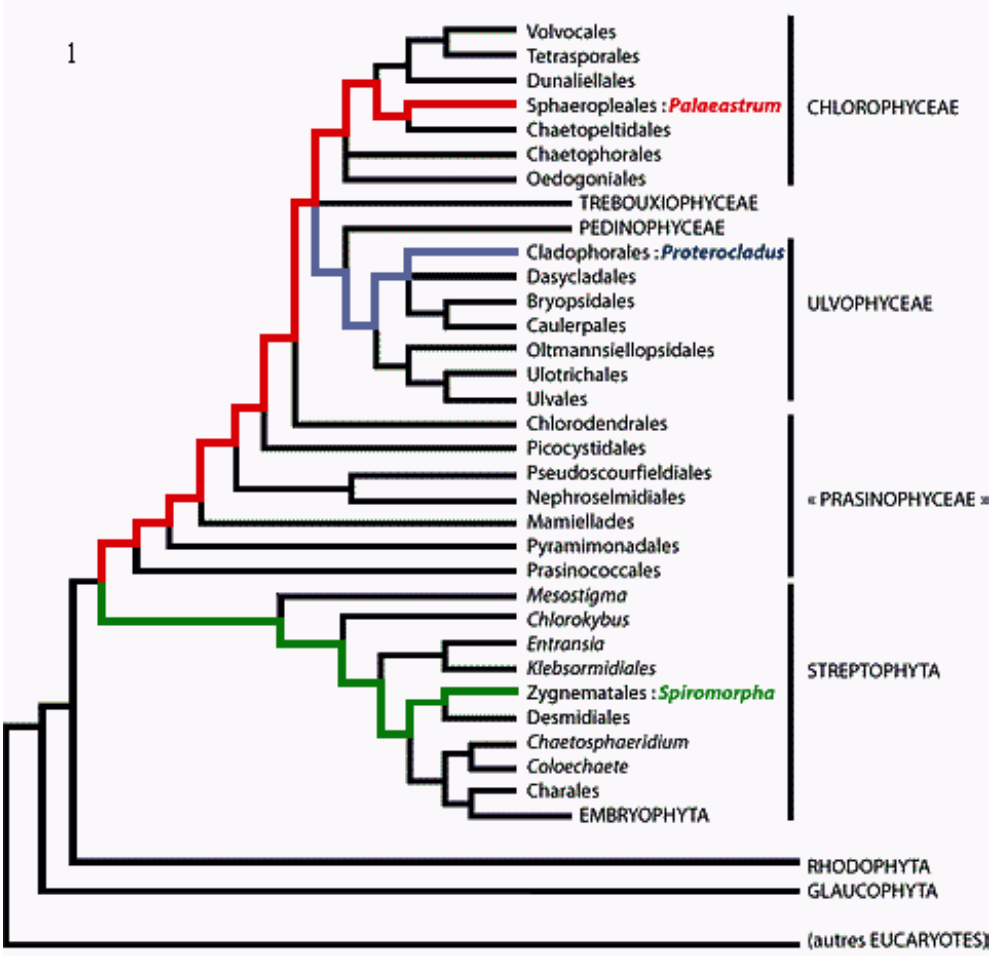

BGD

4, 3123-3142, 2007

The Precambrian radiation of the green algae

B. Teyssèdre

Title Page

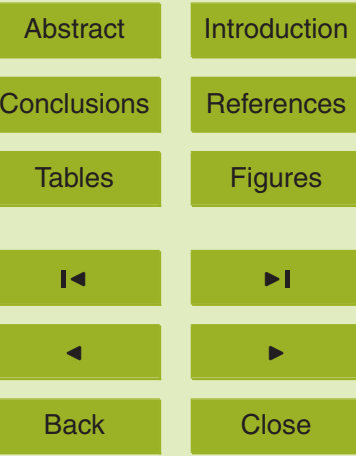

Full Screen / Esc

Fig. 1. Hypothesis concerning the position of three Precambrian green algae on the phylogenetic tree of the Viridiplantae : Palaeastrum (Chlorophyceae, Svanbergfjellet, ca. $750 \mathrm{Ma}$ ), Proterocladus (Ulvophyceae, Svanbergfjellet, ca. $750 \mathrm{Ma}$ ) and Spiromorpha (Zygnematophyceae, Ruyang, ca. 1200 Ma). Reproduced from B.T., Carnets de Géologie, 19 September 2006.

Interactive Discussion 
BGD

4, 3123-3142, 2007

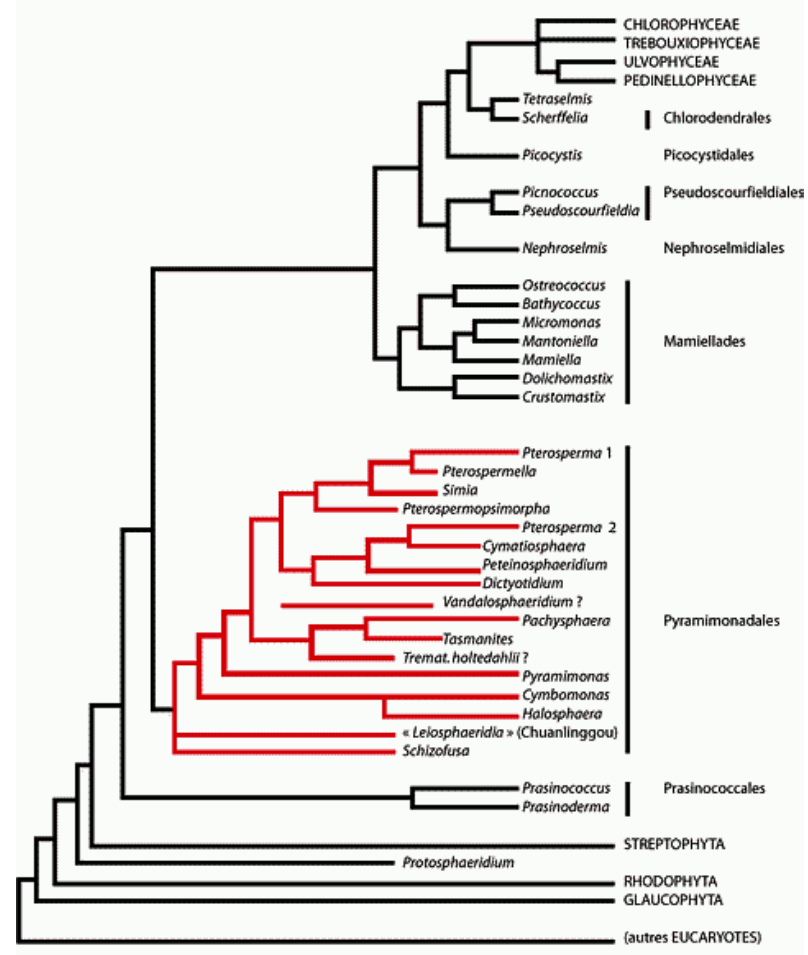

The Precambrian radiation of the green algae

B. Teyssèdre

Title Page

Abstract

Introduction

Conclusions

References

Tables

Figures

14

4

Back

Close

\section{Full Screen / Esc}

Printer-friendly Version

Interactive Discussion of the Viridiplantae. Reproduced from B.T., Carnets de Géologie, 19 September 2006. 
BGD

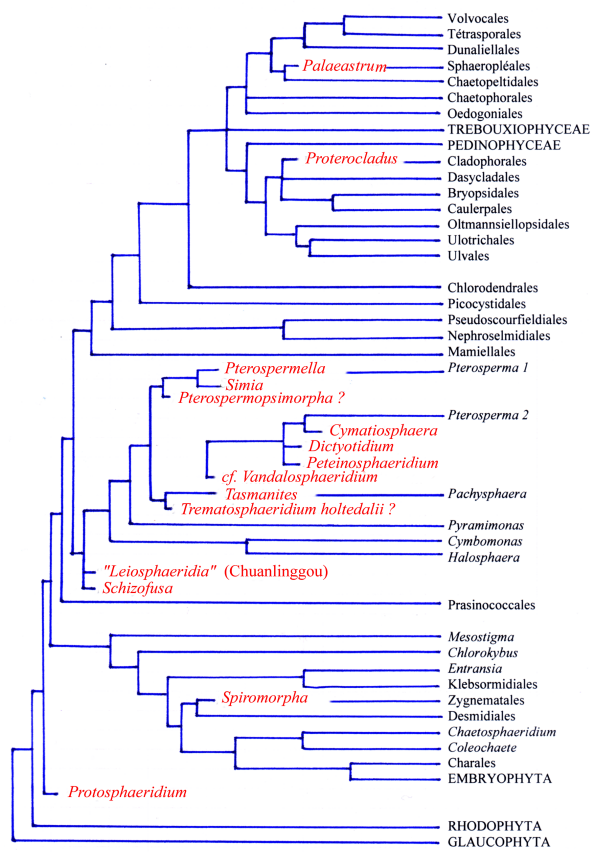

Fig. 3. Approximate indications on the date of the main branchings on the tree of the Viridiplantae, obtained by combination of Precambrian paleontology and molecular phylogeny. The landmarks are some fossils at Hailuoto, ca. $650 \mathrm{Ma}$ (Cymatiosphaera), Svanbergfjellet, ca. 750 Ma (Palaeastrum, Proterocladus, Dictyotidium), Hunnberg, ca. $780 \mathrm{Ma}$ (Peteinosphaeridium), Thulé, ca. $1200 \mathrm{Ma}$ (Pterospermella, Simia, Tasmanites, cf. Vandalosphaeridium), Ruyang, ca. $1200 \mathrm{Ma}$ (Spiromorpha), Zigazino-Komarovsk, ca. $1350 \mathrm{Ma}$ (Pterospermopsimorpha?, Trematosphaeridium holtedahlii ?), Chuanlinggou, ca. $1730 \mathrm{Ma}$ (“Leiosphaeridia”, Schizofusa) and Ladoga, ca. 2000 Ma (Protosphaeridium).
4, 3123-3142, 2007

The Precambrian radiation of the green algae

B. Teyssèdre

Title Page

Abstract

Introduction

Conclusions

References

Tables

Figures

14

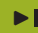

4

Back

Close

\section{Full Screen / Esc}

Printer-friendly Version

Interactive Discussion 


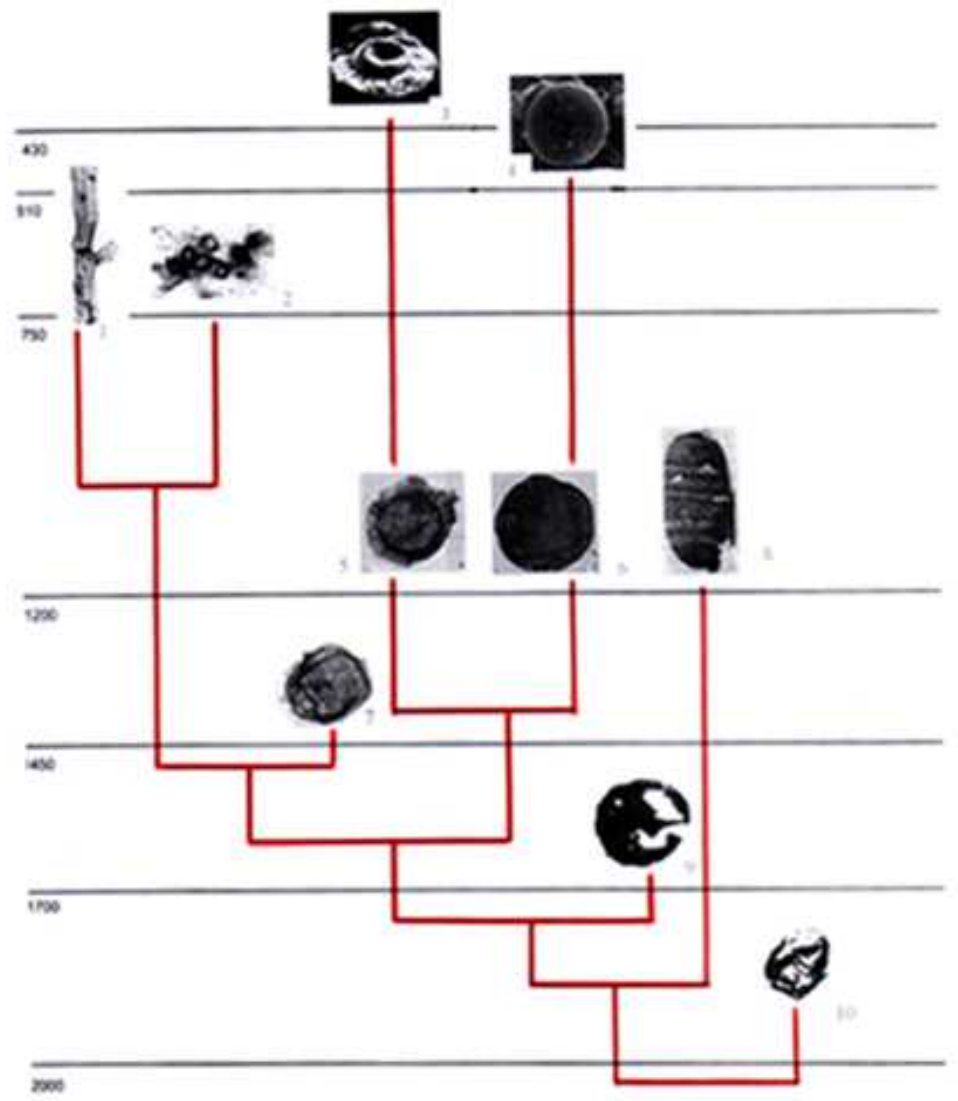

Fig. 4. Tentative correlation of the paleontological occurrence of some well preserved fossils and their position on the phylogenetical tree of the Viridiplantae: 1. Proterocladus. 2. Palaeastrum. 3,5. Pterospermella. 4,6. Tasmanites. 7. "Leiosphaeridia". 8. Spiromorpha. 9. Schizofusa. 10. Protosphaeridium.
BGD

4, 3123-3142, 2007

The Precambrian radiation of the green algae

B. Teyssèdre

Title Page

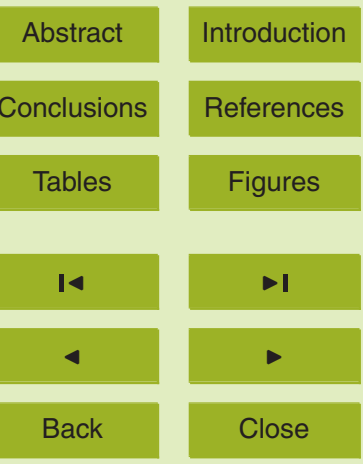

Full Screen / Esc

Printer-friendly Version

Interactive Discussion 